\title{
$\mathrm{CaC}_{2}-\mathrm{CaF}_{2}$ 系フラックスによる高クロム溶鋼の脱りん*
}

\author{
片山裕 之**. 梶岡博 幸** \\ 稲 富 実***. 原島和 海****
}

\section{Dephosphorization of Molten High Chromium Steel with $\mathrm{CaC}_{2}-\mathrm{CaF}_{2}$ Flux}

\author{
Hiroyuki Katayama, Hiroyuki KajIOKA, \\ Makoto InATOMI, and Kazuumi Harashima
}

Synopsis:

The appropriate conditions for dephosphorizing $18 \% \mathrm{Cr}$ molten steel in a crucible with $\mathrm{CaC}_{2}-\mathrm{CaF}_{2}$ flux and the method to make the slag harmless were investigated in a $100 \mathrm{~kg}$ induction furnace.

(1) When the initial $[\mathrm{C} \%]$ is $0.5-1.8 \%$, the degree of dephosphorization is high $(50-80 \%)$. The influence of the initial $[\mathrm{C} \%]$ is explained by consideration of the amount of the remained $\mathrm{CaC}_{2}$ and the ratio of $\frac{\left(\mathrm{CaC}_{2}\right)}{(\mathrm{Ca})}$.

(2) The suitable $\mathrm{CaF}_{2} \%$ in the flux is about $10 \%$ when the temperature of molten steel is between $1580^{\circ} \mathrm{C}$ and $1650^{\circ} \mathrm{C}$.

(3) The slag after dephosphorization should be oxidized until $\left(\mathrm{CaC}_{2} \%\right)$ becomes under $0.1 \%$ to prevent the generation of $\mathrm{PH}_{3}$. For the purpose, two methods were investigated. One is to vapourize phosphorus from the slag by oxygen blowing. The other is to separate the slag from the dephosphorized steel, and subsequently to oxidize the slag in contact with plain carbon steel.

\section{1. 緒誩}

高クロム溶鋼を酸化精錬によつて脱りんすることは, フラックスとして特殊なもの（例： $\mathrm{CaF}_{2} \%$ が高いもの， ソーダ灰) を用いても困難であるといわれている12). そのため，従来，ステンレス鋼の $[\mathrm{P}] \%$ を低くするた めには，ク口ム添加前の溶鋼の脱りんを強化するか ${ }^{314)}$, クロム源の一部として低りんのもの（金属クロムや，脱 クん处理した低炭素フェロクロム5)）を使用することが 行われてきた。しかし，最近になつて，ステンレス鋼溶 製の主クロム源である高炭素フェロクロムの $[\mathrm{P}] \%$ ア ップや，低りんが要求されるステンレス鋼種の增加のた めに，安価に $[\mathrm{P}] \%$ を調整する方法として高クロム溶 鋼を直接脱りんできることが望まれている，その原理と
しては，すでに， $\mathrm{Ca}-\mathrm{CaF}_{2}$ あるいは $\mathrm{CaC}_{2}-\mathrm{CaF}_{2}$ 系フ ラックスによる還元脱りん法が報告されている(6) 8).

本研究では， $\mathrm{CaC}_{2}-\mathrm{CaF}_{2}$ 系フラックスによる還元脱 りん法を量産ステンレス鋼溶製に応用するための条件を 㭇討した．解決すべき問題は次の 3 点である.

（イ）ESR 方式のような水冷銅鋳型を用いた再溶解 法ではなく，溶鋼を直接処理できること，そのために は，耐火物浸食を許容限内に沶さえながら効率的に脱り んできるよらなフラックス条件を見出す必要がある。

(口) $\mathrm{CaC}_{2}-\mathrm{CaF}_{2}$ 系フラックスを用いると, $\mathrm{CaC}_{2}$ の分解反応 :

$$
\left(\mathrm{CaC}_{2}\right) \rightarrow(\mathrm{Ca})+2[\mathrm{C}]
$$

が脱りん進行の前提条件になる．したがつて，処理前溶 鋼の $[\mathrm{C}] \%$ が，フラックスの利用効率や加炭量に影響

* 昭和 52 年 4 月本会苝演大会にて発表 昭和 53 年 10 月 20 日受付 (Received Oct. 20，1978)

** 新日本製鉄 (株)生産技術研究所工博 (Process Technology R \& D Laboratories, Nippon Steel Corp., 1-1 -1 Edamitsu-cho Yawatahigashi-ku Kitakyushu 805)

*** 新日本製鉄(株)生産技術研究所（現：八幡製鉄所）(Process Technology R \& D Laboratories, Now Yawata Works Nippon Steel Corp.)

***** 新日本製鉄(株)基礎研究所 (Fundamental Research Laboratories, Nippon Steel Corp.) 
Table 1. Composition of materials for flux.

- Calciun carbide

\begin{tabular}{|c|c|c|c|c|c|c|c|c|}
\hline $\mathrm{CaO}$ & Si & $A \ell$ & $\mathrm{Fe}$ & $\mathbf{P}$ & $s$ & $\mathbf{N}$ & c & $\mathrm{CaC}_{2}$ \\
\hline $\begin{array}{l}10.3 \\
\sim 13.6 \%\end{array}$ & $\begin{array}{l}0.8 \\
\sim 1.2 \%\end{array}$ & $\begin{array}{l}0.2 \\
\sim 0.5 \%\end{array}$ & $\begin{array}{l}0.6 \\
\sim 0.7 \%\end{array}$ & $0.02 \%$ & $\begin{array}{l}0.9 \\
\sim 1.4 \%\end{array}$ & $\begin{array}{l}0.4 \\
\sim 1.3 \%\end{array}$ & $\begin{array}{l}1.3 \\
\sim 2.0 \%\end{array}$ & bal. \\
\hline
\end{tabular}

- Pure fluer spar

\begin{tabular}{|c|c|c|c|c|c|c|}
\hline $\mathrm{CaF}_{2}$ & $\mathrm{Al}_{2} \mathrm{O}_{3}$ & $\mathrm{SiO}_{2}$ & $\mathrm{~K}_{2} \mathrm{O}$ & $\mathrm{Na}_{2} \mathrm{O}$ & $\mathrm{P}$ & $\mathrm{S}$ \\
\hline $96.7 \%$ & $0.20 \%$ & $0.36 \%$ & $0.97 \%$ & $0.17 \%$ & $0.010 \%$ & $0.019 \%$ \\
\hline
\end{tabular}

することが考兄られる．処理前溶鋼の適正条件を明らか にし，ステンレス鋼溶製のどの段階でこの処理を行うの が最適であるかを検討する必要がある.

（八）脱りん後のスラグは放置すると冷却時に,

$\left(\mathrm{Ca}_{3} \mathrm{P}_{2}\right)+3 \mathrm{H}_{2} \mathrm{O} \rightarrow 3(\mathrm{CaO})+2 \mathrm{PH}_{3}$.

の反応により $\mathrm{PH}_{3}$ (フォスフィン) を発生する. これ を防止できるようなスラグ処理法を含むトータルシステ ムを考光る必要がある.

本研究では $100 \mathrm{~kg}$ 高周波誘導溶解炉を用いた実験に より， $18 \% \mathrm{Cr}-\mathrm{Fe}$ 合金を対象として，上記諸項目につ いて検討した.

\section{2. 試 験 方 法}

$18 \% \mathrm{Cr}$ 鋼を $80 \sim 100 \mathrm{~kg}$ 溶解し, $\mathrm{Al}$ 脱酸して排涬す る. ついで, フードをかぶせ, 雲囲気を Ar 圆換してか ら粉状フラックスを添加する. フラックスはカルシウム カーハイイドと螢石の混合物である，それぞれの組成を Table 1 に示す. カルシウムカーバイドは溶銑脱硫用の もので， $\mathrm{CaC}_{2} \%$ の異なる 3 銘柄を用いた。䖝石は原石 を処理して眽石分を分離した精製物である.
主要な脱り几試験条件を Table 2 に示す.フラック スを添加後，適当な時間間隔で溶鋼のサンプリングを行 い， [P]，[S ]，[C] などの挙動を調べた。また，脱 りん終了後，スラグの酸化実験を行い，溶鋼，スラグ, ダストなどの試料を採取して，りんの挙動を調べた.

鋼中成分の分析は，[P] はモリブデン青吸光光度法, [C] と [S] は然焼法で行つた。 スラグ，ダストなど の試料は，Ar 封入気密瓶に入れて分析直前まで保存 し, $\left(\mathrm{CaC}_{2}\right)$ はアセチレンガス発生 $\rightarrow$ 硝酸銀吸収容量法 で，(T．P）はモリブデン青吸光光度法で，りん化物と

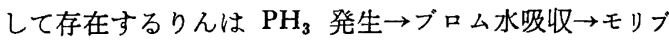
デン青吸光光度法で, 他は学振法で定量した.

\section{3. 試 験 結 果}

（1）脱りん挙動

フラックス添加後数分たつと, フードの隙間から炬外 に噴出するガスが強い光を出して然燒しはじめる，然焼 により白色粉 $(\mathrm{CaO})$ を生ずることから，炉内では $\mathrm{Ca}$ 蒸気を生成していることが伺える．Ca 炎の発生はフラ ックス添加後 7〜10 分で最大となり, 以後, 時間の経 過とともに減少する．なお，Ca 炎は処理前溶鋼 [C] が $0.5 \%$ 以下の時に特に激しい。一方， $2 \%$ 以上の場 合には，Ca 炎はほとんど認められない。

フラックス添加後の溶鋼の典型的な成分挙動を Fig. 1 に示寺. [P], [S ], [O] の低下之加炭が扰こつて いる. $[\mathrm{Cr}],[\mathrm{Mn}]$ はほとんど变化せず， [Si] はわず かに上昇している．[Si] 上昇はカルシウムカーパイト 中の不純物の侵入，あるいは残留していたスラグ中の

Table 2. Experimental conditions.

\begin{tabular}{|c|c|c|c|c|}
\hline \multicolumn{2}{|r|}{ Items } & \multicolumn{2}{|c|}{ Standard experiment } & Comparative experiment \\
\hline \multirow{7}{*}{\multicolumn{2}{|c|}{$\begin{array}{l}\text { Initial composition } \\
\text { of molten steel }\end{array}$}} & \multicolumn{3}{|c|}{$0.30 \sim 3.40 \%$} \\
\hline & & $C_{r}$ & $17.5 \sim 18.5 \%$ & \\
\hline & & $\mathrm{Si}$ & $0.01 \sim 0.03 \%$ & \\
\hline & & $\mathrm{Mn}$ & $0.01 \sim 0.02 \%$ & \\
\hline & & & $0.03 \sim 0.04 \%$ & $0.005 \sim 0.016 \%$ \\
\hline & & 5 & $0.02 \sim 0.04 \%$ & \\
\hline & & & $0.004 \sim 0.025 \%$ & \\
\hline \multicolumn{2}{|c|}{$\begin{array}{l}\text { Temper ature of } \\
\text { molten steel }\end{array}$} & \multicolumn{2}{|c|}{$1580 \sim 1600^{\circ} \mathrm{C}$} & $1550^{\circ} \mathrm{C}, 1650^{\circ} \mathrm{C}$ \\
\hline \multicolumn{2}{|c|}{ Refractory } & \multicolumn{2}{|c|}{ Magnesia (stamped) } & $\left.\begin{array}{l}\text { Mag-dolo } \\
\text { Mag-chro } \\
\text { Alumina }\end{array}\right\}$ (stamped) \\
\hline \multirow{3}{*}{ Flux } & System & ( Calcium & )$-\left(\begin{array}{l}\text { Pure fluor } \\
\text { spar }\end{array}\right)$ & $\left(\begin{array}{l}\text { Calcium } \\
\text { carbide }\end{array}\right)-\left(\begin{array}{l}\text { Pure fluor } \\
\text { spar }\end{array}\right)-($ Magnesia $)$ \\
\hline & $\begin{array}{l}\text { Fluor spar } \\
\text { in flux }\end{array}$ & \multicolumn{3}{|r|}{$0 \sim 35 \%$} \\
\hline & $\begin{array}{l}\text { Quantity } \\
\text { of calcium } \\
\text { carbide }\end{array}$ & \multicolumn{2}{|c|}{$\begin{array}{c}20 \sim 30 \mathrm{~kg} / \mathrm{t} \text {-steel } \\
\left(\mathrm{CaC}_{2}: 20 \sim 25 \mathrm{~kg} / \mathrm{t}\right)\end{array}$} & $\begin{array}{c}6 \sim 35 \% \\
\left(\mathrm{CaC}_{2}: 5 \sim 29 \mathrm{~kg} / \mathrm{t}\right)\end{array}$ \\
\hline
\end{tabular}




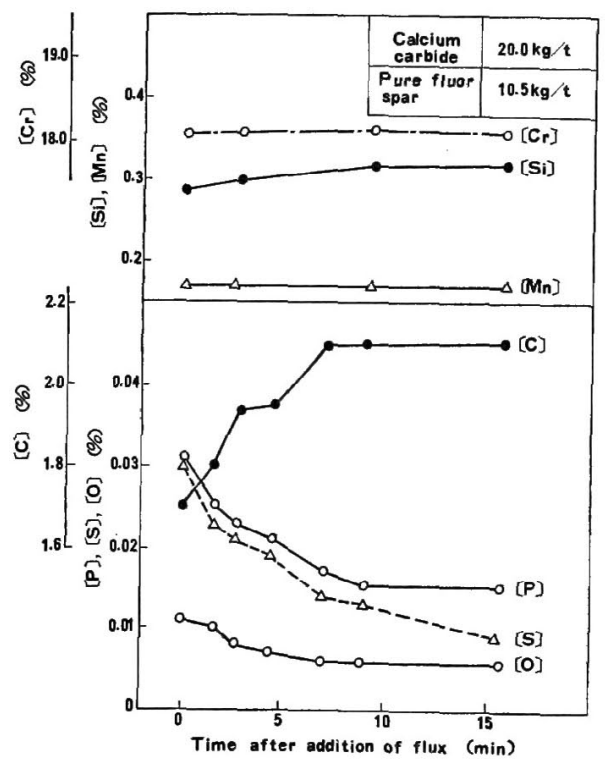

Fig. 1. Typical change in composition of molten steel after flux addition.

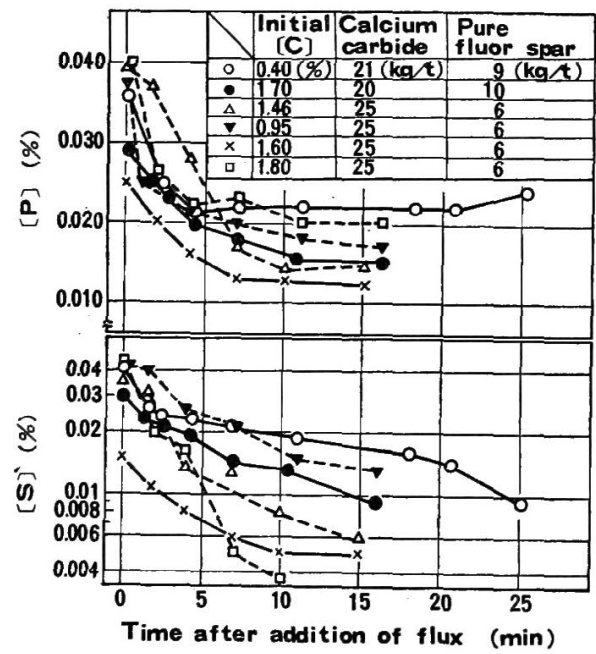

Fig. 2. Changes in [P] and $[\mathrm{S}]$ of $18 \% \mathrm{Cr}$ steels after flux addition.

$\mathrm{SiO}_{2}$ が還元されたためであろう.

[P], [S] の経時変化の数例を Fig. 2 江示す. [S] は 15 分後でも低下を続けているのに対し，[P] 世 10 分 後にはほぼ一定値に達している。 20 分後には得りんが 認められる場合もある. 以後, 脱りん成績は 15 分後で の脱りん率で比較することにする.

フラックス添加後の加炭拉よび脱りんの進行は処理前 [C]％に依存する (Fig. 3). 処理前 [C]％が低いと

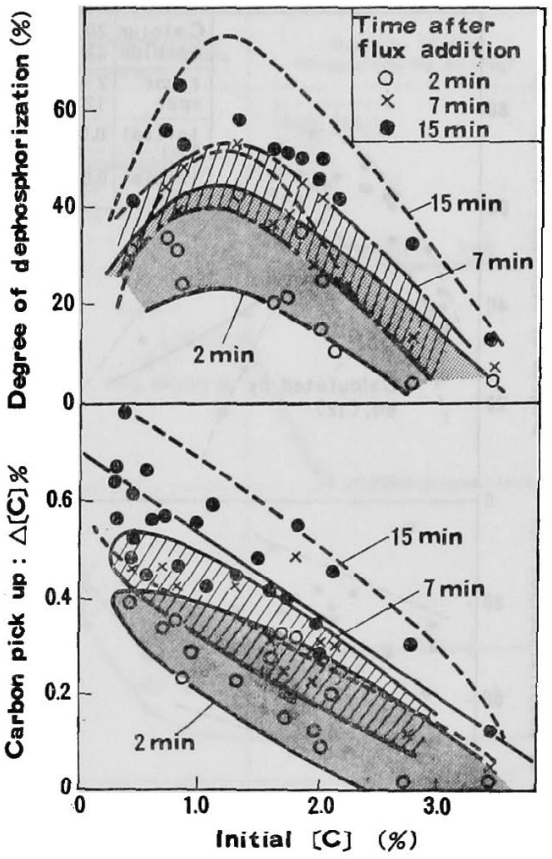

Fig. 3. Influence of initial $[\mathbf{C}]$ on the degree of dephosphorization and carbon pick up. $\left(\begin{array}{cc}\text { Flux : } & \\ \text { calcium carbide } & 20 \sim 25 \mathrm{~kg} / \mathrm{t} \\ \text { oure fluor spar } & 2 \sim 12 \mathrm{~kg} / \mathrm{t}\end{array}\right)$

初期の加炭速度が大きく，（1）式により生成する $\mathrm{Ca}$ 量 が多いことを伺わせる.しかし，脱りんの進行は[C]： $1.0 \%$ 以下では, 加炭と対応していないことが注目され る.

15 分後での脱りん率と脱硫率にお上ぼす処理前 [G] \% の影響を Fig. 4 に示す. 処理前 [C] : 0.5 1.8\% の時, 脱りえ率としては高い値が得られている. 脱硫率 については処理前 $[\mathbf{C}] \%$ の影響は小さいが，脱りんの 場合とは異なり，[C]\%が高い汪ど大きくなる傾向が 認められる。な捄，フラックス添加前の [O] は 200 ppm 以下（ほとんどの場合，80〜130 ppm) であり，あ らかじめ $\mathrm{Al}$ 脱酸しているので $[\mathrm{O}]$ と [C] の間には 相関はない。

Fig. 5 はフラックス中の $\mathrm{CaC}_{2}$ 分の原単位と脱りん 率の関係を示す. 近似的に

脱り几率 $=A \times\left(\mathrm{CaC}_{2} \text { 原単位 }\right)^{0.6}$

で整理できる、ここで，A は处理前 $[\mathrm{C}] \%$ に依存する 定数であり， $[\mathrm{C}]: 0.30 \sim 0.55 \%$ の時は 5.51 (\%) $\left.(\mathrm{kg} / \mathrm{t})^{06}\right)$, [G] : 0.95 1.80\% の時は $8.77(\% /(\mathrm{kg} /$ t) 0.6 ) である.

フラックス中の $\mathrm{CaF}_{2}$ 配合率と脱りん率の関係をFig. 


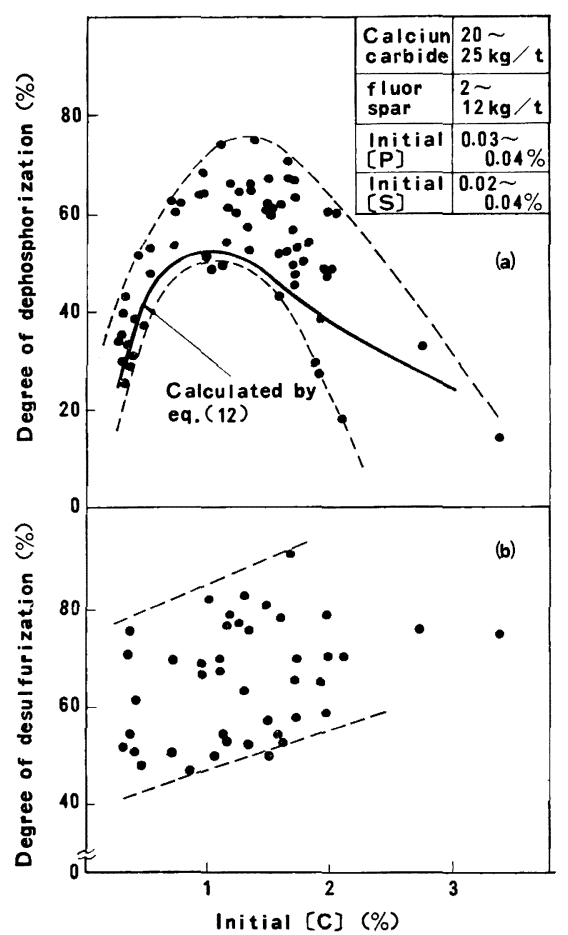

Fig. 4. Influence of the initial [C] on the degree of dephosphorization and desulphurization at $15 \mathrm{~min}$ after addition of flux.

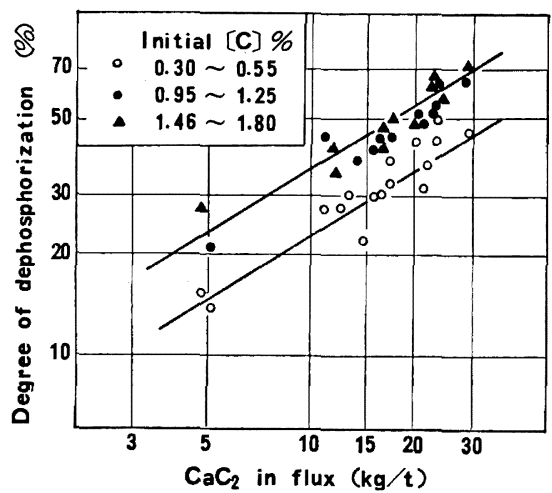

Fig. 5. Influence of the quantity of $\mathrm{CaC}_{2}$ on the degree of dephosphorization.

6 に示す. $\mathrm{CaF}_{2}$ を加えないと，脱りんはほとんど進 行しない，適正な $\mathrm{CaF}_{2}$ 配合率は溶鋼温度に依存し， $1580 \sim 1650^{\circ} \mathrm{C}$ では 5〜20\%，1500〜1550 ${ }^{\circ} \mathrm{C}$ では 30 〜 40\% である. $\mathrm{CaF}_{2} \%$ が高すぎると，耐火物溶損の影 響で脱りん率は低下する.

カルシウムカーパイド中の $\mathrm{CaC}_{2} \%$ が脱りん率におよ ぽす影響は，フラックスの $\mathrm{CaC}_{2}$ 原単位を一定とすれ ば，比較的小さい.しかし，フラックスに他の酸化物を

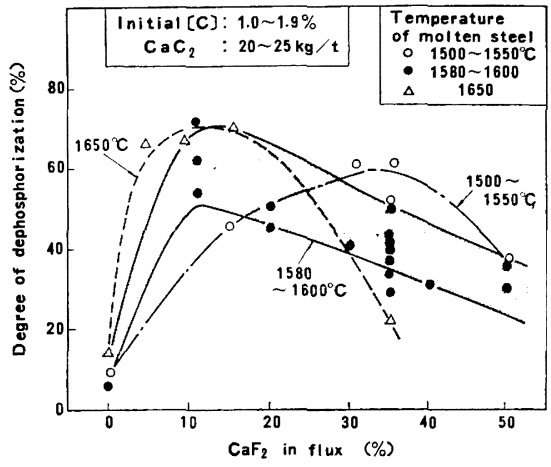

Fig. 6. Influence of $\mathrm{CaF}_{2} \%$ in the flux and the temperature of molten steel.

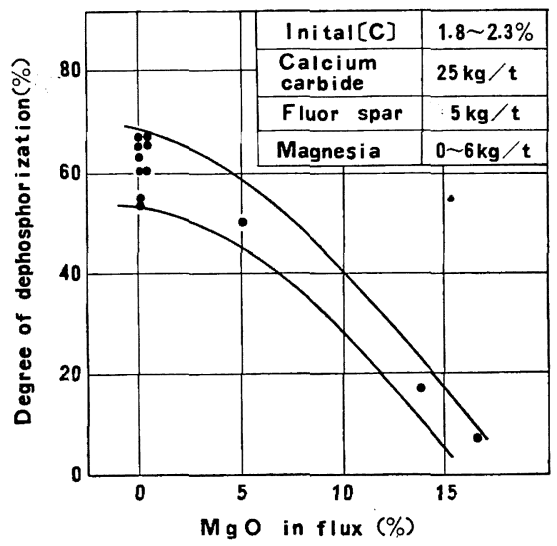

Fig. 7. Influence of $\mathrm{MgO}$ in the flux on the degree of dephosphorization.

加えると（1例を Fig. 7 に示す），脱りん率は著しく 低下する。これは

$$
(\mathrm{MgO})+(\mathrm{Ca}) \longrightarrow(\mathrm{CaO})+\mathrm{Mg}
$$

の反応により，スラグ中の $\mathrm{Ca}$ が減少するためと考えら れる。

Fig. 8 は耐火物種類の影響を示す. 得られる脱りん 率はマグネシア，マグクロ，マグドロでは差は認められ なかつたが，アルミナの場合にはかなり低くなつてい る.これは, アルミナが $\mathrm{CaO}$ と反応して低融点化して スラグに入り，Ca を酸化しやすくするためと考兄られ る.

Fig. 9 は処理前 $[\mathrm{P}] \%$ を変化させた時の脱りん挙 動を示す，同一の処理条件では，処理前 $[\mathrm{P}] \%$ に関係 なくほぽ一定の脱りん率が得られる。

(2) 脱りん後スラグの安定化処理

$\mathrm{PH}_{3}$ 発生を防止するには， スラグ中にりん化物とし て存在するりんを酸化する必要がある，そのために，種 


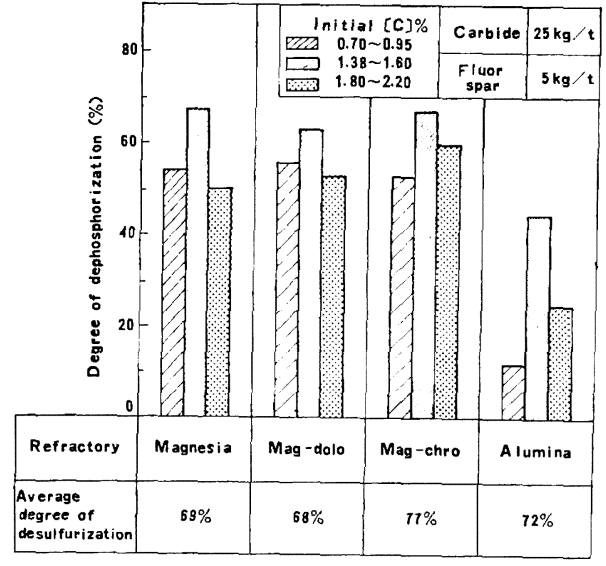

Fig. 8. Influence of the refractory material on the degree of dephosphorization and desulphurization.

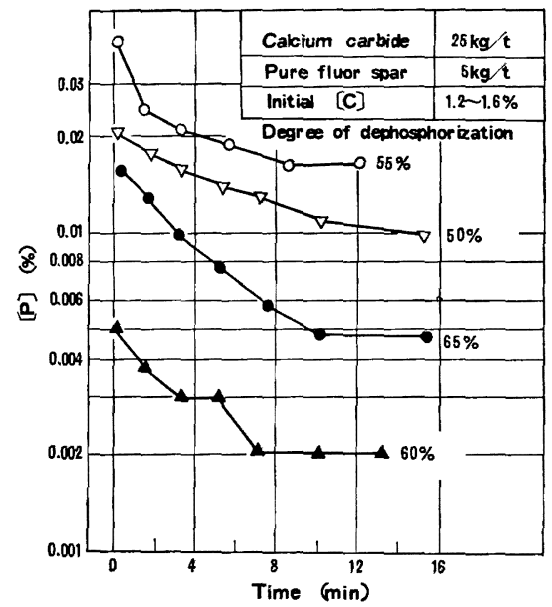

Fig. 9. Behaviour of dephosphorization at different initial [P] levels.

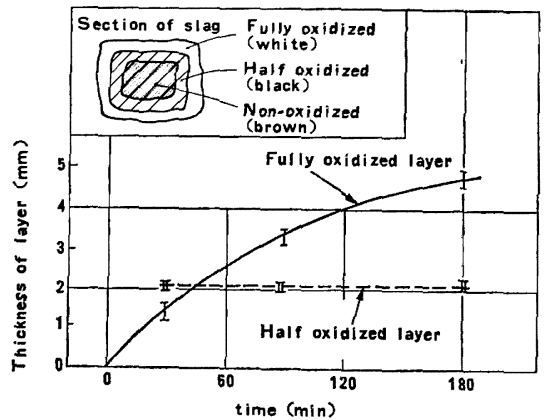

Fig. 10. Behaviour of oxidation of $\operatorname{slag}(30 \mathrm{~mm} \phi)$ at $900^{\circ} \mathrm{C}$ in the air.

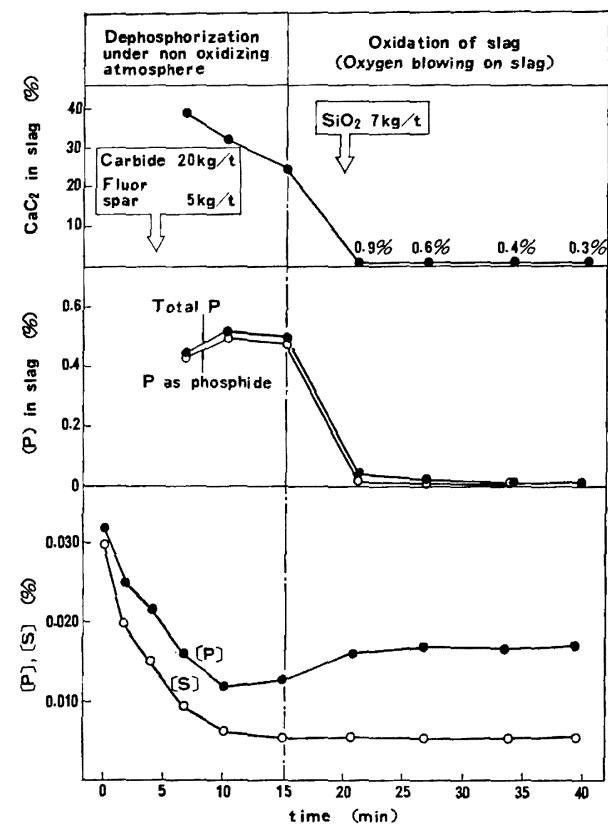

Fig. 11. Example of behaviour of phosphorus during the dephosphorization and oxidation of slag.

々の条件でスラグの酸化実験を行つた。

凝固後のスラグの酸化処理

塊状スラグを高盜酸化性雲曲気にさらすと，外側から 層状に酸化が進行する (Fig. 10). 最外層の白色部は水 につけてもがスを発生せず，完全に安定化されたと見な せる、この層の厚さ $(d)$ は，注ぼ

$$
d=k v \bar{t}
$$

で裴せる. $k$ は温度に依存する定数で， $900^{\circ} \mathrm{C}$ では 0.36 $\mathrm{mm} / \mathrm{min}^{1 / 2}$ である.（5）式によると, 例えば $30 \mathrm{~mm} \phi$ の塊状スラグを完全に安定化するには 116 時間かかるこ とになり，実用的とは言い難い。

溶融スラグの酸化処理（その1)

まず，脱りん終了後そのままの状態で（スラグを溶鋼 から分離することなく）酸化した．Fig.11は脱りん処 理の後期からスラグ酸化期における溶鋼, スラグ成分の 挙理の 1 例を示す．脱りん期にはスラグ中のりんは，ほ とんどりん化物として存在している、スラグを酸化する と，りん化物として存在するりんは減少するが，その 際, 酸化物として存在するりんは增加与るわけではな い、したがつて，スラグを酸化してりんを酸化物として 保定することは，この場合は不可能であることがわか る.

Table 3 に示す分析例にもとづいて，スラグ酸化時の 
Table 3. Composition of the slag before and after oxidation, refractory and dust.

(a) Slag before oxidation

\begin{tabular}{|c|c|c|c|c|c|c|c|}
\hline $\mathrm{C}_{a} \mathrm{C}_{2}$ & $\begin{array}{l}P \text { as } \\
\text { phosphide }\end{array}$ & $\begin{array}{l}P \text { as } \\
\text { oxide }\end{array}$ & $\mathrm{CaO}$ & $\mathrm{MgO}$ & T. Fe & $\mathrm{T}, \mathrm{Cr}$ & $F$ \\
\hline $12 \sim 40 \%$ & $0.2-1.3 \%$ & $\begin{array}{l}0.004 \\
\sim 0.057 \%\end{array}$ & $\begin{array}{l}13 \\
\sim 58 \%\end{array}$ & $\begin{array}{l}0.5 \\
\sim 16.2 \%\end{array}$ & $\begin{array}{l}0.4 \\
\sim 5.4 \%\end{array}$ & $\stackrel{2}{\sim 5 \%}$ & $\begin{array}{l}3.6 \\
\sim 26 \%\end{array}$ \\
\hline
\end{tabular}

(b) Slag after oxidation

\begin{tabular}{|l|l|l|}
\hline $\mathrm{CaF}_{2}$ & $\begin{array}{l}P \text { as } \\
\text { phosphide }\end{array}$ & $\begin{array}{l}P \text { as } \\
\text { oxide }\end{array}$ \\
\hline 0.03 & 0.0015 & 0.015 \\
$\sim 4.2 \%$ & $\sim 0.062 \%$ & $\sim 0.10 \%$ \\
\hline
\end{tabular}

(c) Refractory at slag-line $(30 \sim 50 \mathrm{~kg} / \mathrm{t})$

\begin{tabular}{|l|c|l|l|l|}
\hline $\mathrm{MgO}$ & \multicolumn{1}{|c|}{$\mathrm{CaO}$} & $\mathrm{SiO}_{2}$ & $\mathrm{Al}_{2} \mathrm{O}_{3}$ & \multicolumn{1}{|c|}{$\mathrm{P}$} \\
\hline 63.5 & 15.1 & 6.8 & 2.2 & 0.05 \\
$-78.0 \%$ & $\sim 24.0 \%$ & $\sim 7.5 \%$ & $\sim 2.6 \%$ & $\sim 0.09 \%$ \\
\hline
\end{tabular}

(at) Dust $(6 \sim 10 \mathrm{~kg}$ t)
\begin{tabular}{|l|l|l|l|l|l|l|l|l|l|}
\hline $\mathrm{T} . \mathrm{CaO}$ & $\mathrm{SiO}_{2}$ & $\mathrm{MgO}$ & $\mathrm{A} \ell_{2} \mathrm{O}_{3}$ & $\mathrm{~T} . \mathrm{Fe}$ & $\mathrm{T} . \mathrm{Cr}$ & $\mathrm{P}$ & $\mathrm{S}$ & \multicolumn{1}{|c|}{$\mathrm{F}$} & Ig. loss \\
\hline 13 & 0.7 & 0.1 & 1 & 3 & 0.2 & 0.2 & 0.2 & 5 & 12 \\
$\sim 61 \%$ & $\sim 3.9 \%$ & $\sim 5.0 \%$ & $\sim 7 \%$ & $\sim 21 \%$ & $\sim 0.8 \%$ & $\sim 0.6 \%$ & $\sim 21 \%$ & $\sim 10 \%$ & $\sim 18 \%$ \\
\hline
\end{tabular}

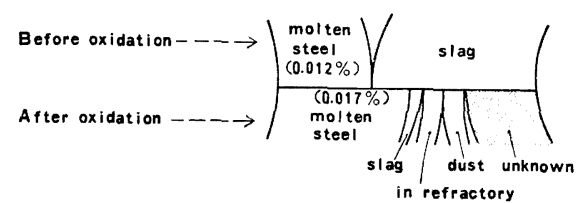

Fig. 12. An example of phosphorus balance.

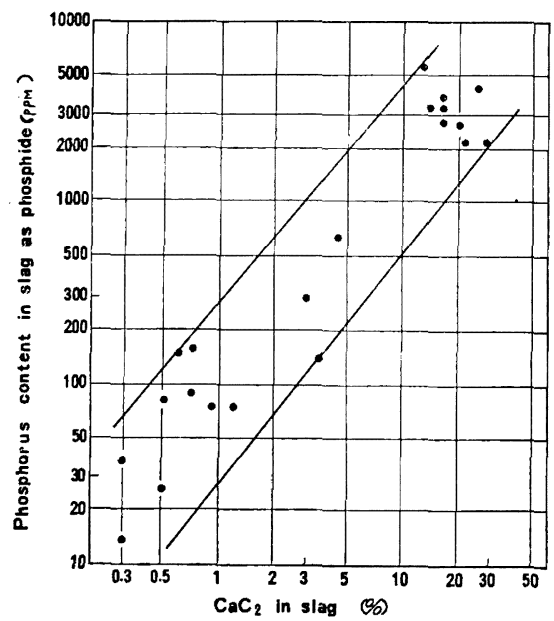

Fig. 13. Relation between $\mathrm{CaC}_{2} \%$ and phosphorus content existing in slag as phosphate.

りんバランスをとると，かなりの量のりんが行方不四に なつている (Fig. 12).このりんの行先について種々检 討の結果，酸化時の排ガスを水に通すと，り几酸カルシ ウムの沈測として捕捉されることがわかつた．これは， スラグ中にりん化物として存在していたりんが酸化され

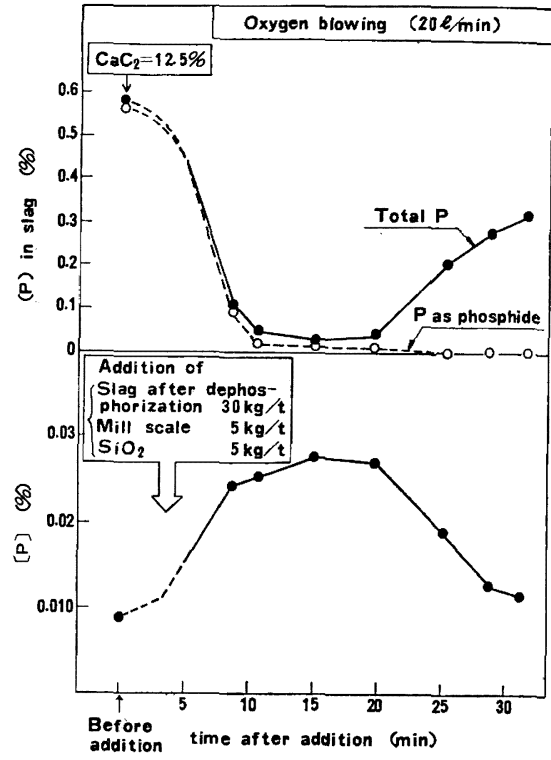

Fig. 14. Behaviour of phosphorus in slag and steel when the slag after dephosphorization are oxidized in contact with low carbon steel (C: $0.08 \%$ ).

て，蒸気圧の高い元素りんあるいは亜酸化物となつて気 化したためと考えられる.

スラグを酸化する時の復りん率は，溶鋼比表面積，濹 找状況，スラグ性状 $\left(\mathrm{SiO}_{2}\right.$ 添加量）などに依存する。 $100 \mathrm{~kg}$ 実験の場合, 復りん率は 5 40\% の範囲であ る.

Fig. 13 はスラグ中の $\mathrm{CaC}_{2} \%$ 之,りん化物として存 在するりん量の関係を示す。 $\mathrm{CaC}_{2} \%$ の低下とともに, 门ん化物として存在するりん量は减少する。. $\mathrm{PH}_{3}$ 発生 を防止するには， $\mathrm{CaC}_{2} \leq 0.1 \%$ まで酸化することが望 ましい。

溶融スラグの酸化処理（その2)

脱りんスラグを高クロム溶鋼から分唯後，別の溶鋼 (例兄ば低炭素溶鋼) と接触させて酸化する方式を試験 した．試験は，あらかじめ作つて打いた含りん $\mathrm{CaC}_{2}$ $\mathrm{CaF}_{2}-\mathrm{CaO}$ 系スラグを, [G]: 0.08\% の炭素溶鋼に添 加して吹酸する方法である.なお，スラグとともにミル スケールと川砂を加えた. Fig. 14 に示すように，スラグ の酸化の進行とともに， $\mathrm{CaC}_{2} \%$ 㧊よびり儿化物として 存在与るりんは急速に低下し，それに対応して [P]は いつたん上昇する。 ミルスケールを加えると, 単に吹酸 する場合に比べて，スラグから気化するりんの割合は著 しく小さくなる(復りん率：約 88\%)。ささらに吹酸を続 けると通常の酸化脱りん反応が扣こり, 最終的にりんは 


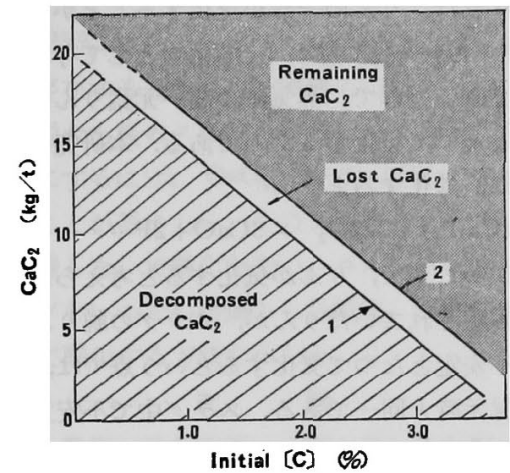

Fig. 15. Influence of initial [C] on the distribution of added $\mathrm{CaC}_{2}$ at $15 \mathrm{~min}$.

(Added $\mathrm{CaC}_{2}: 22 \mathrm{~kg} / \mathrm{t}$ )

$\left(\begin{array}{l}\text { Line } 1: \text { calculated from Fig. } 3 \\ \text { Line } 2: \text { assumed }\end{array}\right.$

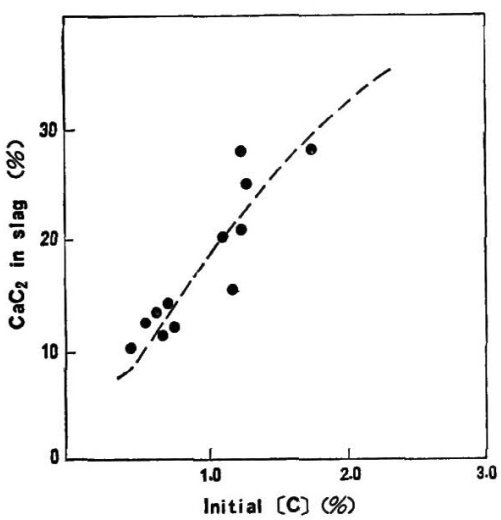

Fig. 16. Relation between initial [C] and $\left(\mathrm{CaC}_{2}\right)$ in slag at $15 \mathrm{~min}$ after addition of flux.

酸化性スラグ中にりん酸カルシウムとして固定される．

この方式は，炭素溶鋼が使えることか゚前提となるが，

高クロム溶鋼に復りんさせることなくスラグを安定化で きるという特徵がある。

\section{4. 考察}

\section{1 脱りんの適正条件}

（1）式により生成した Ca は，次のいずれかの挙耐を する。

(i) スラグ中に Ca として残留する.

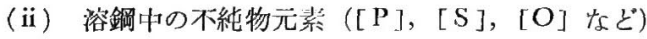
と結合する.

(iii） スラグや耐火物中の酸化物，あるい憬国父中 の酸素によつて酸化されて $\mathrm{CaO}$ となる。

(iv) 蒸発する。

$\mathrm{CaC}_{2}-\mathrm{CaF}_{2}$ 系フラックスにより効率的に脱りんする
ためには，雾围気，耐火物，フラックス中の酸化物系不 純物に留意して (iii) 在抑制するとともに，Ca 生成速 度をコントロールして蒸発損失（iv）を極力少なくし， (i) あるいは (ii) として用いられる Ca の割合を多 くすることが重要である。

実験結果によると，特に処理前 [C]％の影響が顕著 に認められた (Fig. 3). その理由を以下で検討してみ る.

フラックス中の $\mathrm{CaC}_{2}$ の分解量は, Fig. 3 に示した 加炭量から逆算できる。 また, ある量のカルシウムカー バイドは分解することなく飛散することを考虑すると， 添加後 15 分での残留 $\mathrm{CaC}_{2}$ 量は Fig. 15 のように推 定される. 処理前 $[\mathrm{C}] \%$ との間に強い相関がある. ま た, その時点でのスラグ中の $\mathrm{CaC}_{2} \%$ (分析値) と処理 前 $[\mathrm{C}] \%\left([\mathrm{G}]_{0}\right)$ の間には Fig. 16 のような関係が あり,ほぼ

$$
\left(\mathrm{CaC}_{2}(\%)\right)=18[\mathrm{C}(\%)]_{0}^{0.86}
$$

で近似できる. Fig. 15 と Fig. 16 から $\mathrm{CaC}_{2}$ バラン スによりスラグ量を計算すると，

$$
\left.\begin{array}{rl}
\text { スラグ量 }(\mathrm{kg} / \mathrm{t}) \\
\quad=36[\mathrm{C}(\%)]_{0}^{0.49}-6.0\left([\mathrm{G}]_{0} \leq 1.0 \%\right) \\
=36[\mathrm{C}(\%)]_{0}^{0.12}-6.0\left([\mathrm{C}]_{0}>1.0 \%\right)
\end{array}\right\}
$$

で表せる。

15 分後の平均溶鋼 [C] は, Fig. 3 の結果を用いる と,

$$
\begin{aligned}
{[\mathrm{C}(\%)] } & =[\mathrm{C}(\%)]_{0}+\Delta[\mathrm{C}(\%)] \\
& =[\mathrm{C}(\%)]_{0}+0.70-0.18[\mathrm{C}(\%)]_{0} \\
& =0.70+0.82[\mathrm{C}(\%)]_{0} \cdots \cdots \cdots \cdots \cdots
\end{aligned}
$$

となる。

(1) 式の $\mathrm{CaC}_{2}$ 分解反応の見かけの平衡関係として, 中村は次の関係を得ている9).

$$
\frac{\left[\mathrm{CaC}_{2}(\%)\right]}{[\mathrm{Ca}(\%)]}=2.0[\mathrm{C}(\%)]^{1.92}
$$

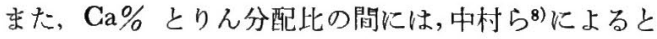

$$
\frac{[\mathrm{P}(\%)]}{[\mathrm{P}(\%)]}=2.39(\mathrm{Ca} \%) \mathbf{1 . 9 4}
$$

が成立している。

脱りん終了時点で，溶鋼から除かれたりんはすべてス ラグ中に存在しているとすれば, 脱りん率々りん分配比 の関係は(13)式で近似できる。

脱りん率 $(\%)$

$$
\begin{aligned}
& =\frac{(\text { 溶鋼から除去されたりん髽） }}{(\text { 処理前溶鋼中のりん昌 })} \times 100 \\
& \approx \frac{(\text { 処理後スラグ中のウん量 }) \times 100}{\left(\begin{array}{l}
\text { 処理後溶鋼 } \\
\text { 中のりん量 }
\end{array}\right)+\left(\begin{array}{l}
\text { 処理後スラグ } \\
\text { 中のりん量 }
\end{array}\right)}
\end{aligned}
$$


Table 4. Relations between the intial [G] and the degree of dephoshorization calculated by eq. (12)

\begin{tabular}{|c|c|c|c|c|c|c|}
\hline $\begin{array}{l}\text { Initial } \\
\text { (c) \% }\end{array}$ & $\mid \begin{array}{l}\text { CC } \% \text { at } \\
15 \mathrm{~min}\end{array}$ & $\begin{array}{c}\text { Quantity } \\
\text { of slag } \\
\text { at } 15 \mathrm{~min} \\
(\mathrm{~kg} / \mathrm{t})\end{array}$ & $\left\{\begin{array}{l}\mathrm{CaC}_{2} \% \\
\text { in slag } \\
\text { at } 15 \mathrm{~min}\end{array}\right.$ & $\begin{array}{l}\text { Ca } \% \text { in } \\
\text { slag at } \\
15 \text { min } \\
\text { (eq. (9) }\end{array}$ & $\begin{array}{l}\frac{(P)}{(P)} \text { at } \\
15 \mathrm{~min}\end{array}$ & $\begin{array}{l}\text { Degree of } \\
\text { dephospho- } \\
\text { rization at } \\
15 \mathrm{~min}\end{array}$ \\
\hline 0.30 & 0.95 & 14.0 & 6.4 & 3.53 & 27.6 & 27.8 \\
\hline 0.50 & 1.11 & 19.6 & 9. 9 & 4.05 & 36.0 & 41.4 \\
\hline 0.70 & 1.27 & 24.2 & 13.2 & 4. 17 & 38.1 & 47.9 \\
\hline 1.00 & 1.52 & 30.0 & 18.0 & 4.03 & 35.7 & 51.7 \\
\hline 1.50 & 1.93 & 31.8 & 25.5 & 3.61 & 28.8 & 47.8 \\
\hline 2.00 & 2.34 & 33.1 & 32.7 & 3.20 & 22.8 & 43.0 \\
\hline 2.50 & 2.75 & 34.2 & 39.5 & 2.83 & 17.9 & 37.9 \\
\hline 3.00 & 3.16 & 35.1 & 46. 3 & 2.54 & 145 & 33.7 \\
\hline
\end{tabular}

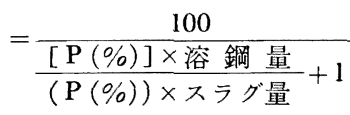

(6)，（7)，（8)，（9，，(10)，（11)式を組み合せる 之, 脱りん率は $[\mathrm{C}(\%)]_{0}$ の関数として $(12)$ 式で表せる. 脱りん率 $(\%)$

$$
=\frac{100}{2.39\left[\left.\frac{\left(18[\mathrm{C}]_{0}^{0.86}\right)}{2.0\left(0.70+0.82[\mathrm{C}]_{0}\right)^{1.92}}\right|^{1.94} \times\left(\begin{array}{c}
\text { スラ } \\
\text { グ量 }
\end{array}\right)\right.}+1
$$

各 $[\mathrm{C}(\%)]_{0}$ に対する計算結果を Table 4 に示す. また，その結果を Fig. 4 に書き込んでいる。処理前 [C]：2\% 以下では, 計算によつて得られる曲線の形 は，奏験結果とよく一致している.

処理前 [C] が $0.5 \%$ 以下の場合には, $\mathrm{CaC}_{2}$ 分解反 応が迅速に進行し，生成した過剩の $\mathrm{Ca}$ が蒸発するため に, 15 分後での $\mathrm{CaC}_{2}$ 残留量およびスラグ量が少な くなるので脱りん能は小さくなる. 一方, 処理前 [C] が $2.0 \%$ 以上では， $\mathrm{CaC}_{2}$ 残留量は多いが，(9)式によ り $\mathrm{Ca} \%$ が低くなるので，やはり脱りんには不利にな る.

なお，脱りん率の絶対值は央験結果の方が計算值より も高くなつている。その理由としては，(10)式の関係は ESR 方式で得られたもので，本試験とはスラグの温度 条件が異なつていることなどが考光られる.

効率的に脱りんを行らには，処理前 [C] は 0.5 $1.8 \%$ の範囲であることが望ましい。これは,ステンレス 溶製工程において，仕上げ脱炭前の粗溶鋼の [C]\%と ほぼ一致している，したがつて，本処理は，浴解・一次 精錬工程と仕上げ脱炭工程の間で行うことが最適であ る.

\section{$4 \cdot 2$ 脱りん後スラグ安定化の適正条件}

りんを含有する酸化性スラグや鉄鉱石を適当な条件下
で還元すれば，りんの一部が気化することが知られてい る(0) 14). これらはいずれも,酸化物として存在するりん が還元される過程で, 蒸気圧の高い元素りんあるいは亜 酸化物となつて気化するためである. 本研究の脱りん後 スラグは，酸化すると

$$
\left(\mathrm{Ca}_{3} \mathrm{P}_{2}\right)+3 / 2 \mathrm{O}_{2} \rightarrow 3 \mathrm{CaO}+2 \mathrm{P}
$$

の反応が抗こつて，りんが気化寸ると考えられる。 スラ グ中に固定されていたりんが，スラグの脱りん能低下に よつて不安定となつて気化するといら点では，酸化性ス ラグの還元時と同一である．スラグ中で不安定となつた りんが気化するか，あるいは溶鋼に戻るかは，スラグ溶鋼，スラグ雲囲気の接触条件に依存する．気化脱りん 率 $\left(\frac{\text { スラグ酸化により気化したりん量 }}{\text { 脱りん後のスラグ中のりん量 }}\right)$ を高めるには, （イ）溶鋼一スラグの 接触比表面積を小さくし， かつ溶 鋼の攪䢁を抑制する，（口）スラグ一雾围気の 接触比表 面積を大にする (酸化時の $\mathrm{CO}$ 発生の利用), (八) 雲囲 気側のりんの移動が抵抗にならないように減圧にするな どの方法が考えられる. ある程度の復りんが許容される 場合には，脱りん後，スラグを高クロム溶鋼から分離す ることなく，仕上げ脱炭を行うことによりスラグの安定 化も行える．なお，炭素溶鋼が利用きる場合には，前述 のように，高クロム溶鋼から分離したスラグを加えて酸 化精鍊する方法もある.

\section{5. を め}

$\mathrm{Ca}$ 含有スラグによる還元脱りん法を量産ステンレス 鋼溶製工程に応用するために，耐火物容器内の $18 \% \mathrm{Cr}$ 溶鋼を $\mathrm{CaC}_{2}-\mathrm{CaF}_{2}$ 系フラックスで処理する適正条件お。 よび脱りん後のスラグ安定化について， $100 \mathrm{~kg}$ 規模の 試験を行つた。

（1） [S] は時間とともに低下するのに対し， [P] は約 10 分後にはほぼ一定值に達する。 20 分後には復 りんが認められる場合もある.

(2) 処理前溶鋼 [C] が $0.5 \sim 1.8 \%$ の範囲の時, 高い脱りん率が得られる $(40 \sim 75 \%)$. これは，残留 $\mathrm{CaC}_{2}$, スラグ量, $\frac{\left(\mathrm{CaC}_{2}(\%)\right)}{(\mathrm{Ca}(\%))}$ を考慮すれば説明でき る.

（3）フラックス中の $\mathrm{CaC}_{2}$ 原単位と得られる脱りん 率の間には

脱りん率 $(\%)=A \times\left(\mathrm{CaC}_{2} \text { 原単位 }\right)^{0.6}$ の圈係がある．ただし，定数 $A$ は処理前 $[\mathrm{C}] \%$ に依存 する。

(4) フラックス中の適正 $\mathrm{CaF}_{2}$ 配合率は溶鋼温度に 依存し，1580 1650 ${ }^{\circ} \mathrm{C}$ の時は約 $10 \%, 1500 \sim 1550^{\circ} \mathrm{C}$ 
の時は約 35\% である.フラックス中に還元されやずい 酸化物が存在すると脱りん能は著しく低下する.

(5) 脱りん後のスラグを安定化して $\mathrm{PH}_{3}$ を発生し ないようにするには, $\mathrm{CaC}_{2}: 0.1 \%$ 以下になるように 酸化することが望ましい，その方法として，スラグを溶 鋼から分離しないで酸化を行い，りんを気化させる方法 と, スラグをいつたん溶鋼から分離後, 別の炭素溶鋼と 接触させて酸化する方法を示した。

\section{文献}

1) 沢 繁樹, 泶谷正吾, 金原茂: 鉄と鋼, 55 (1969) 13, p. 1183

2 ) 染野 檀, 川上正博: 学振製鋼 19 委提出資料, No. 19-9809 (1975)

3 ) 神居詮正, 大久保静夫, 恵藤文二: 鉄と鋼, 63 (1977) 13, p. 2064

4) 片山裕之, 稲富実, 梶岡博幸, 山本里見, 田中 英夫：鉄と鋼，62 (1976) $2, \mathrm{~A}-17$

5) V.P. ZAIKo: Stal in Eng., (1964)9, p. 915
6 ) 徳光直樹, 原島和海, 中村 沶: 鉄と铜, 63 (1977) 13, p. 2172

7 ) 中村 泰, 井藤三千寿, 原島和海：鉄と鋼, 64 (1978) 3, p. 402

8 ) 中村 泰, 原島和海, 井藤三千寿: 鉄と鋼, 63 (1977) 4, S 102

9 ) 中村 泰：私信

10）塩見純雄，佐野信雄，松下幸雄：鉄と鋼， 63 (1977) 9, p. 1520

11) 中村 泰, 井藤三千寿, 石川英毅：鉄と鋼, 63 (1977) 4, S 12

12）旛 林三, 中西恭二, 鈴木健一郎, 江島涁夫, 川原田 昭, 関明：鉄と鋼，63 (1977) 11, S 624

13）竹内秀次, 金子恭二郎, 佐野信雄, 松下幸雄：鉄 鋼協会第 95 回講演大会, ボスターセッション 6 (1978)

14）塩見純雄，佐野信雄，前田正史，松下幸雄：鉄之 鋼, 64 (1978) 4, S 175 